\title{
Is Higher Education A Potential Means of Promoting Labour Mobility?
}

\author{
Banerjee Minali ${ }^{1}$ and Singh Manju ${ }^{2}$ \\ ${ }^{1}$ School of Humanities and Social Science, Manipal University Jaipur, Jaipur-303007, Rajasthan, India. \\ ${ }^{2}$ School of Humanities and Social Sciences, Manipal University Jaipur, Jaipur-303007, Rajasthan, India.
}

\begin{abstract}
Background/Objectives: The Article supports the hypothesis that in the Globalised era, a country can develop by globalising its workforce. India is having the youngest population in the world and is continuously facing the challenge of educating its young population and preparing them to meet the Global competition. Its struggle to provide employment to its increasing workforce can be resolved by providing efficient education which will increase inter- regional and international student mobility and as a result will make the workforce more Globalised. Methods/Statistical analysis: Therefore the Article shows a strong positive relation between Education (preferably Higher Education), Student mobility and labour mobility and concludes that an increase in one of these factor results in an increase in the other two. Findings: Indian Higher education system is in its nascent stage where Gross enrolment ratio (GER) is low as compared to other developing countries like China. Ministry of Human resource development (MHRD) revealed that Gross enrolment ratio for higher education in India increased to 24.5 per cent in 2015-16. Improvements/Applications: NGOs, Government employees, teachers and educators can group together and educate people about Higher education. They can also inform students about importance of higher education for their career and society as whole and ways and means by which they can acquire one in India and abroad.
\end{abstract}

\section{Index Terms}

Globalisation, Higher education, Labour mobility, Student mobility

\author{
Corresponding author : Minali Banerjee \\ minalibanerjee2012@gmail.com \\ - Manuscript received March 17, 2018. \\ - Revised March 25, 2018 ; Accepted March 27, 2018. \\ - Date of publication March 31, 2018. \\ (C) The Academic Society of Convergence Science Inc. \\ 2546-1583 $\odot 2017$ IJEMR. Personal use is permitted, but republication/redistribution requires IJEMR permission.
}




\section{INTRODUCTION}

Globalisation is the need of an hour. Present scenario supports the conviction that "the more a country is globalised, the faster is its growth".

Globalisation of labour simply refers to mobility of labour. Though 'Globalisation' formally came in 1985, describing the changes in global economics [1], it had its traces long back in 1829 when 1.3 million Indians travelled to various sugar colonies to work in sugar plantations between 1829 to 1917 [2]. This could be fittingly referred to as the dawn of labour mobility.

The paper deroles the importance of labour mobility for a developing country (focusing on India) as labours work as a pollen and transport technology, goods and capital from one place to another. Globalisation of labour basically deals with the international mobility but for increasing international mobility, inter regional mobility should be increased.

Inter regional mobility of labour refers to mobility of labour within a country and it results in a strong positive effect on entrepreneurship [3, 4]. As highly mobile individuals have a taste of variety which enhances their creativity and creativity is the root to entrepreneurship. Entrepreneurship leads to increased job creation [5] which increases the demand for labour and induces labour to move within and between countries. As also found that increased labour mobility between foreign and local firms results in increased job creation by local firms [6]. Also, [7] while assuming constant returns to capital proved that labour mobility and growth works in the same direction. As labour mobility increases, growth increases.

Inspite of the known importance of labour mobility, some developing countries like India are lacking behind in this aspect. The migration rate for working adult males ranges from 4 per cent to 5.4 per cent and the wage gap is higher in India as compared to China and other developing and developed countries [8]. Difference in the marginal productivity of labour, a primary cause of wage gap, is basically due to lack of inward mobility [9]. In order to bridge the inter-regional wage gap, inter-regional labour mobility should be increased.

One of the successful measures to increase labour mobility is increasing student mobility. Student mobility increases labour mobility as studying abroad increases the chance of an individual's working in a foreign country [10].

\section{MethodologY}

The paper is based on secondary data. The data is taken from different research articles, books, journals and various net based sources.

\section{EDUCATION AND STUDENT MOBILITY}

Student mobility is increasing these days. Both developing and developed countries are emphasising on exchange of students. The factor on which the concept of student mobility relies is EDUCATION. Though some of the economists are of the view that education reduces job mobility [11] and decreases the area of work [12] which means more an individual gains specialisation, more one is bound towards doing a particular type of job, some argue that Education makes an individual a better decision maker. An educated individual is more efficient job searcher and changes jobs more easily [13]. One reason might be that education provides a good paced growth in their career which necessitates them to change job more often as an institutional requirement [14]. Also educated individuals have an advantage in learning and using new technology [15] which makes them change job more easily and fruitfully and increases their demand in different sectors.

Education makes an individual skilled thus there arise a productive increase in the population. Therefore, in the era of Globalisation, India should develop work-ready graduates who can harness their skills to transcend the region of ease [16]. This competitive era is emphasising more on the quality and quantity of skilled workers [17]. The quality and quantity can be improved by providing effective education. By effective education we mean education which aims at providing quality to the students and drives the students toward a balanced approach comprising of both practical based knowledge and theoretical based knowledge. As theoretical based knowledge (classroom knowledge) is fruitful if can be applied to the real world. India lacks this approach. Therefore India needs to internationalise its education sector.

\section{INTERNATIONALISATION OF EDUCATION}

Globalisation has bought new challenges which are reducing the pace of growth of developing countries. Education serves as a remedy to meet these challenges as it helps a country to produce 
competent human resources [18]. Human resources in turn are a means to increase a country's competitiveness [19]. Developing native education sector is not enough to fight the Globalisation challenges where practical knowledge is a need so, education itself need to be globalised.

For this Universities should be globalised or internationalised. Internationalisation not only means exchange of students between countries but it also means to provide native students the exposure to international teaching Standards. MOOCS, online courses can help in this respect. Students can learn from foreign faculty while sitting at home.

\section{NOT JUST EDUCATION BUT "HIGHER EDUCATION"}

Higher education is a critical component for human resource development worldwide. As the countries are developing, the demands for skilled individuals are increasing. Higher education provides the necessary analytical skills which helps in driving the economies towards effective growth. [20] showed how countries by increasing the rate of enrolment in higher education and by integrating themselves more closely into the world economy, experienced reduced poverty, higher growth and an increase in the share of trade in GDP.

\section{HIGHER EDUCATION IN INDIA}

Indian Higher education system is in its nascent stage where Gross enrolment ratio (GER) is low as compared to other developing countries like China. Ministry of Human resource development (MHRD) revealed that Gross enrolment ratio for higher education in India increased to 24.5 per cent in 2015-16. This is a big jump as in 2004-05 the GER was only 10 per cent. Whereas China which is the most demanded education destination in Asia among international students, has an advanced higher education system which is majorly responsible for its growth and prosperity. [21,22] supports the fact that Indian public sector is unable to cope up with the rising demand of higher education by the Indian youth. Therefore India should support students going abroad for attaining education (international student mobility). This concept of student mobility which is often considered as brain drain is important at least till India creates its own well developed higher education sector.

\section{RESTRICTIONS ON STUDENT MOBILITY}

Student mobility trend started because there is limited access to education facilities in less developed economies [23]. Various factors are considered by a student while mobilising to some other country to study. These factors are here characterized as Impel and Expel factors.

Where Expel factors are the 'push' factors which refer to the limiting factors that limit the career growth of a student. Impel are the 'pull' factors which refer to the benefits provided by a foreign country that attracts a foreign student. Low Wealth and slow growth rate of GNP of a country results in an increased mobility of students abroad [24]. Low education opportunities and higher cost of education also works as a push factor [25].

Student mobility is also driven with the fact that studying in a university having high brand equity uplifts the economic and social worth of a student. These brand equities are the impel factors of international students. More the brand value of the university more will be the demand for its degree [26].

Degree of innovation, level of technological advancement, resources and promotion and marketing efforts work as a pull factors which pursue an individual to study in that country [27]. Reputation also plays a major role in this domain. The more a country is reputed and develop, more will be the demand of its education among International students [28].

[29] Stated that the degree of involvement of the developing country in the world economy, economic links between the host and the home country are also the factors increasing student mobility. When these impel and expel factors are weak, restriction on student mobility arises.

These days with the increase in globalised economies, global tensions are also increasing. Terrorism, International conflicts, trade agreement, competition among nations in becoming the world power is imposing heavy duty on student mobility.

Though globalisation has brought nations materialistically closer through increase in trade and agreements but has also brought cut-throat competition. This weakens the links between them. Various countries have banned the immigration of nationals from few countries in fear of Terrorism which has limited the educational options for the students living in these countries. Increase in terrorism in few countries is working as a hurdle to 
the mobility of students as parents consider it unsafe to send their wards to terrorism prone areas.

Awareness is also a factor restricting mobility. Informing the students about potential global education destinations is a big challenge for both host and the home countries but is important factor contributing student mobility [30]. Awaring each and every student about the education destinations is quite difficult but not impossible.

Apart from these above mentioned factors, cost of living, travel expenses, social cost such as crime safety and racial discrimination also counts [31]. Language gap is another big restriction. Countries rigid with their native languages create obstacles for foreign students studying there. Political tension among countries also serves as a bottleneck in student mobility. Visa restrictions are primarily responsible in decreasing student mobility. Enrolment of international students in Universities of UK has dropped from 36 per cent to less than 33 per cent in 2010/11 and 2013/14. This is mainly due to restrictions imposed on international mobility to UK.

\section{CONCLUSION}

UNESCO reported that India ranked one of the lowest in providing quality education per every child. In a report named "Impact of Globalisation on Indian Education System", it was stated that Indians incur only 406 dollars for every student in terms of Higher education which is far less than other developing countries. This is the reason why student mobility is necessary. India, one of the fastest growing developing countries is on the path of becoming world's youngest country with a median age of 27.3 and an estimated 28 per cent contribution to the world workforce (Ernst and Young, 2014). This population dividend which India is having is a waste if maximum of its population is unproductive. Skilled workforce is a mandatory criterion for India to flourish and remain one among the fastest growing countries. Education makes an individual capable to adopt changes, be it innovation, new technology or new culture. Skilled (educated) labours are demanded more therefore the more an individual is educated the more one will be demanded abroad which increases international labour mobility. For this inclusive development of Education system is necessary. By Inclusive we mean developing education from its root. This could be done by community based practises at local and national level. NGOs, Government employees, teachers and educators can group together and educate people about Higher education. They can also inform students about importance of higher education for their career and society as whole and ways and means by which they can acquire one in India and abroad.

\section{REFERENCES}

[1] Dar, I. A. (2017). Education in Globalized World. International Journal of Advanced Research and Development. ISSN: 2455-4030, 2(6), 493-494.

[2] Durgahee, R. (2017). The indentured archipelago: experience of Indian indentured labour in Mauritius and Fiji, 1871-1916.

[3] Braunerhjelm, P., Ding, D., \& Thulin, P. (2016). Labour as a knowledge carrier: how increased mobility influences entrepreneurship. The Journal of Technology Transfer, Springer, 41(6), 1308-1326.

[4] Brounerhjelm, P. (2016). Does Innovation lead to firm growth? Explorative versus Exploitative innovation. Swedish Entrepreneurship forum working paper No. 2016:46.

[5] Malchow-Møller, N., Schjerning, B., \& Sørensen, A. (2009). Entrepreneurship, Job creation and wage growth. Centre for Applied Microeconometrics, Denmark, Working paper no. 2009-01.

[6] Saglam, B. B., \& Sayek, S. (2010). Labour market effects of knowledge spill over. METU Studies in Development; Ankara, 37 (3), 195-219.

[7] Raurich, X., Sánchez-Losada, F., \& Vilalta-Bufí, M. (2015). Knowledge misallocation and growth. Macroeconomic Dynamics; Cambridge, 19 (7), 1540-1564.

[8] Munshi, K., \& Rosenzweig, M. Why is labour mobility in India so low? Networks and Misallocation: Insurance, Migration, and the Rural-Urban Wage Gap published in the American Economic Review, 106(1): 46-98

[9] Hamilton, B., \& Whalley, J. (1984). Efficiency and distributional implications of global restrictions on labour mobility: Calculations and policy implications. Journal of Development Economics, 14 (1), 61-75.

[10] Parey, M., \& Waldinger, F. (2011). Studying Abroad and the Effect on International Labour Market Mobility: Evidence from the Introduction of ERASMUS. The Economic Journal, 121(551), 194-222.

[11] Jovanovic, B. (1979). Job Matching and the Theory of Turnover. Journal of Political Economy, 875(1), 972-990.

[12] Strohl, J. (2003). Education and job -to -job mobility: An empirical analysis of Bulgaria and the Czech Republic. American University, ProQuest Dissertations Publishing.

[13] Greenwood, M.J. (1975). Research on Internal Migration in the United States: A Survey. Journal of Economic Literature, 13(2), 397-433.

[14] Borsch-Supan, A. (1987). The role of education: mobility increasing or mobility impeding? National Bureau of Economic Research.

[15] Bartel, A. P., \& Lichtenberg, F. (1987). The comparative advantage of educated workers in implementing new technology. The Review of Economics and Statistics, 69(1), $1-11$.

[16] Chia, S. (2013). The ASEAN economic community: progress, challenges and prospects, ADBI working paper 440.

[17] Hajkowicz, S. (2015). Global Megatrends: Seven Patterns of Change Shaping Our Future. Australia: CSIRO, 2015.

[18] Hassan, R., Masek, A., \& Mohamad, M. M. (2015). The role of networking and internationalization of technical universities in academic staff competence development. TVET@Asia, 5, 1-9. 
[19] Sharma, K.D. (2008). Regional Accreditation: Mechanism for Cross-Border Mobility for TVET Graduates.

[20] Dollar, D., \& Collier, P. (2002). Globalization, growth, and poverty: building an inclusive world economy. A World Bank policy research report. Washington, D.C

[21] Ruch, R.S. (2001). Higher Education Incorporated: The Rise of the for-profit University, Baltimore, John Hopkins University Press.

[22] Varghese, N.V. (2009). Institutional Restructuring of Higher Education in Asia: An Overview, in Higher Education Reforms: Institutional Restructuring in Asia. UNESCO and International Institute of Educational Planning, 27.

[23] Mazzarol, T. \& Soutar, G. N. (2002). Push-pull factors influencing international student destination choice. The International Journal of Educational Management; Bradford, $16(2 / 3), 82-90$.

[24] Lee, K.H., \& Tan, J.P. (1984). The International flow of third level lesser developed country.

[25] Agarwal, V.B., \& Winkler, D.R. (1985). Foreign demand per US higher education: a study of developing country in the eastern hemisphere, Economic development and cultural change, 33(3), 623-44.

[26] Barber, M., Katelyn D., \& Saad, R. (2013). An Avalanche Is Coming. Higher Education and the Revolution ahead. Institute for Public Policy Research.

[27] Mazzarol, T.W. (1998). Critical success factors for international education marketing. International Journal of Education management, 12(4), 163-75.

[28] Kinnell, M. (1989). International marketing in UK higher education: some issues in relation to marketing educational programmes to overseas students. European Journal of marketing, 23(5), 7-21.

[29] McMahon, M.E. (1992). Higher education in the world market: an historical look at the global context of international study. Journal of Higher education, 24(4), 46582.

[30] Mazzarol, T.W., Choo, S., \& Nair, V.S. (2001). Australia and the Indian Postgraduate science and technology market: Examining why.

[31] Mazzarol, T., \& Soutar, G. N. (2002). Push-pull factors influencing international student destination choice. The International Journal of Educational Management; Bradford $16(2 / 3), 82-90$ 